\title{
Sphedamnocarpus andersonii (Malpighiaceae), a new species from Madagascar
}

\author{
Christiane ANDERson
}

University of Michigan Herbarium, 3600 Varsity Drive, Ann Arbor, MI 48108, USA; e-mail: chra@umich.edu

\begin{abstract}
Sphedamnocarpus andersonii, a new species from the Ihorombe Region of Madagascar, is described and illustrated. The twiggy, white-flowered shrubs are characterized by linear leaves, unique in the genus.
\end{abstract}

Keywords: Dioecy, Ihorombe region, Malagasy shrub, Sphedamnocarpus, Stigmaphyllon clade.

Sphedamnocarpus Planch. ex Benth. \& Hook. f. (Malpighiaceae) comprises ca. eight species in southern tropical Africa and ca. 10 species in Madagascar. The fruits are schizocarps that split into three samaras, each with a large dorsal wing, but lacking lateral wings or other ornamentation, and bearing a carpophore. In the generic phylogeny of the Malpighiaceae by Davis and Anderson (2010) Sphedamnocarpus falls into the Stigmaphyllon clade. Niedenzu $(1915,1928)$ presented the first full accounts of Sphedamnocarpus, and Arènes (1943) published the most recent survey of the entire genus. Launert $(1961,1963)$ revisited the African species, but the Malagasy taxa remain in need of revision. Any study incorporating the many new collections from Madagascar obtained during the last 30 years will doubtlessly lead to new interpretations of species boundaries in Sphedamnocarpus and supersede Arènes's often narrow delimitations. The late William R. Anderson, in a review of Malpighiaceae from Madagascar, noted a new species of Sphedamnocarpus from Isalo National Park in the Ihorombe Region, which is here described. Measurements of floral parts given in the description are taken from herbarium material revived with Pohl's solution (Pohl, 1965).

Sphedamnocarpus andersonii C. E. Anderson, sp. nov. Type. Madagascar. Ihorombe Region: Isalo National Park, vicinity of Mangily and
Tombeaux Bara on trail to Piscine Naturelle, ca. $4 \mathrm{~km} \mathrm{SW}$ of Ranohira, ca. $850 \mathrm{~m}$, 22³3.72'S, 45²2.95'E, 9 Mar 2007 (fl, fr), T. F. Daniel 11,025 (holotype: MICH; isotype: CAS).

(Figs. 1, 2)

Diagnosis: Sphedamnocarpus andersonii differs from all other species of Sphedamnocarpus by its linear leaves, and from S. dubardii Viguier \& Humbert ex Arènes and S. poissonii Arènes in its shrubby vs. vining habit.

Twiggy shrub to $1.5 \mathrm{~m}$; stems densely sericeous when young, the vesture reddish, eventually glabrescent and lenticillate. Leaves opposite; lamina of the larger leaves 5-11 $\times$ $0.4-1.8 \mathrm{~cm}$, linear to linear-lanceolate, apex acute to rounded, commonly mucronate, base acute, adaxially and abaxially densely sericeous when young but soon glabrous, the vesture retained on the costa abaxially or not, margins commonly recurved to inrolled, costa adaxially impressed, abaxially prominent; petiole 3-7 $\mathrm{mm}$ long, densely sericeous; glands borne at apex of petiole or partly or sometimes entirely at base of lamina, each gland $0.4-0.8 \mathrm{~mm}$ in diameter, circular, prominent; stipules interpetiolar, 0.5-1 $\mathrm{mm}$ long, triangular, hidden by the dense stem vesture. Plants dioecious. Inflorescence densely reddish sericeous, the ultimate unit a 4-flowered umbel; peduncles absent; pedicels $2-3.7 \mathrm{~mm}$ long, in fruit to $6 \mathrm{~mm}$ long and stouter, densely sericeous, 

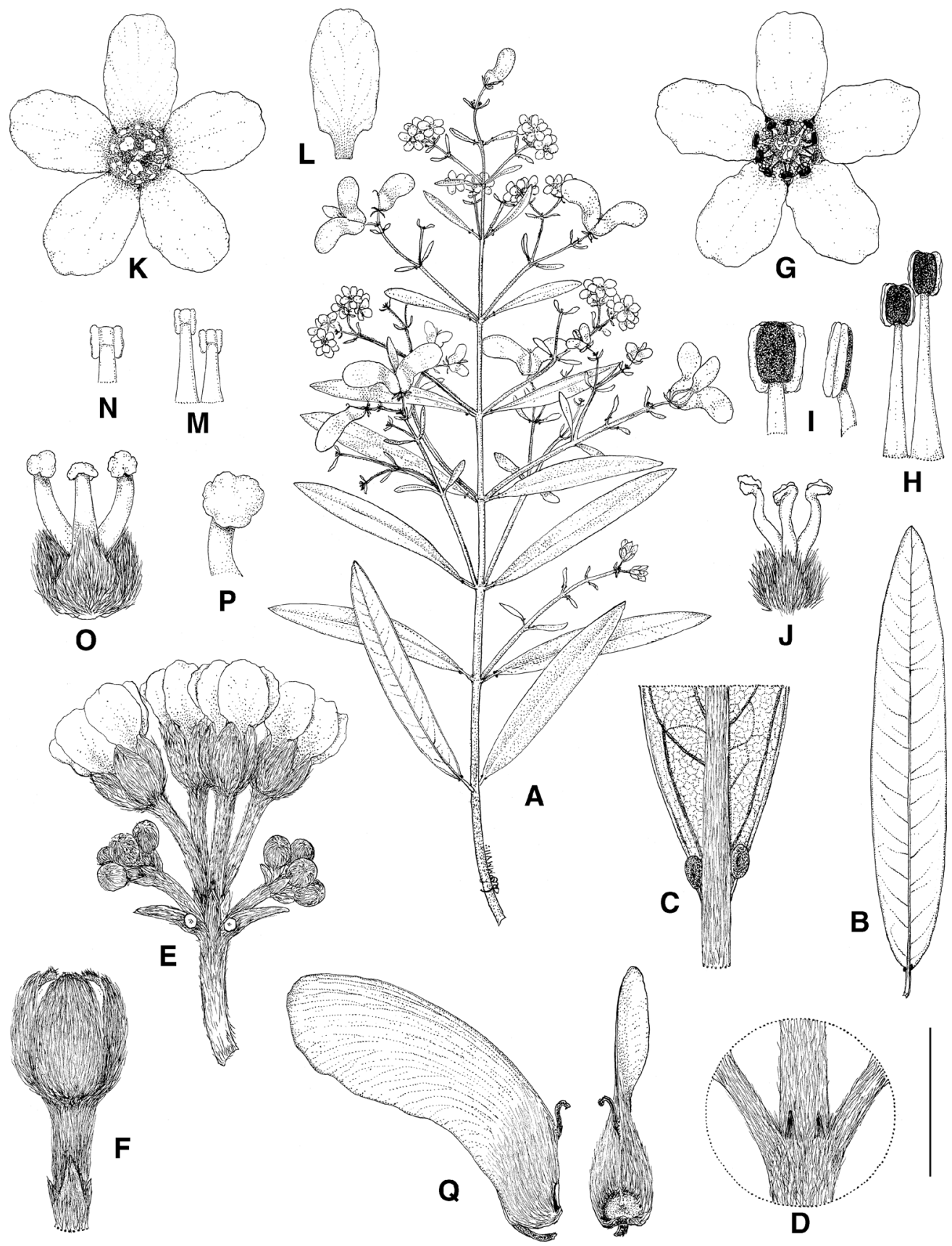

H

Fig. 1. Sphedamnocarpus andersonii. A. Branch with flowers and fruits. B. Detached large leaf, abaxial view. C. Base of lamina, abaxial view. D. Node with interpetiolar stipules. E. Umbel of four flowers just opening, subtended by very young lateral umbels. F. Flower bud about to open, subtended by the bract and two bracteoles. G. Staminate flower from above. H. Two stamens from staminate flower, abaxial view, that on right opposite a sepal, that on left opposite a petal. I. Anthers from staminate flower, abaxial view (left) and lateral view (right). J. Gynoecium from staminate flower. K. Pistillate flower from above. L. Petal from pistillate flower, adaxial view. M. Two stamens from pistillate flower, abaxial view, that on left opposite a sepal, that on right opposite a petal. N. Anther from pistillate flower. O. Gynoecium from pistillate flower. P. Apex of style from gynoecium of pistillate flower. Q. Samaras, lateral view (left) and adaxial view (right). Scale bar equivalents: A, B, 4 cm; C, D, 4 mm; E, $5.7 \mathrm{~mm}$; F, $2.7 \mathrm{~mm}$; G, $4 \mathrm{~mm}$; H, $2 \mathrm{~mm}$; I, $1.3 \mathrm{~mm}$; J, $2 \mathrm{~mm}$; K, L, $4 \mathrm{~mm}$; M, $2 \mathrm{~mm}$; N, $1.3 \mathrm{~mm}$; O, $2 \mathrm{~mm}$; P, $1 \mathrm{~mm}$; Q, 8 mm. (A, C, D, K-Q, from the holotype; B, Labat et al. 2126, MO; E-J, Phillipson 4104, MICH). 

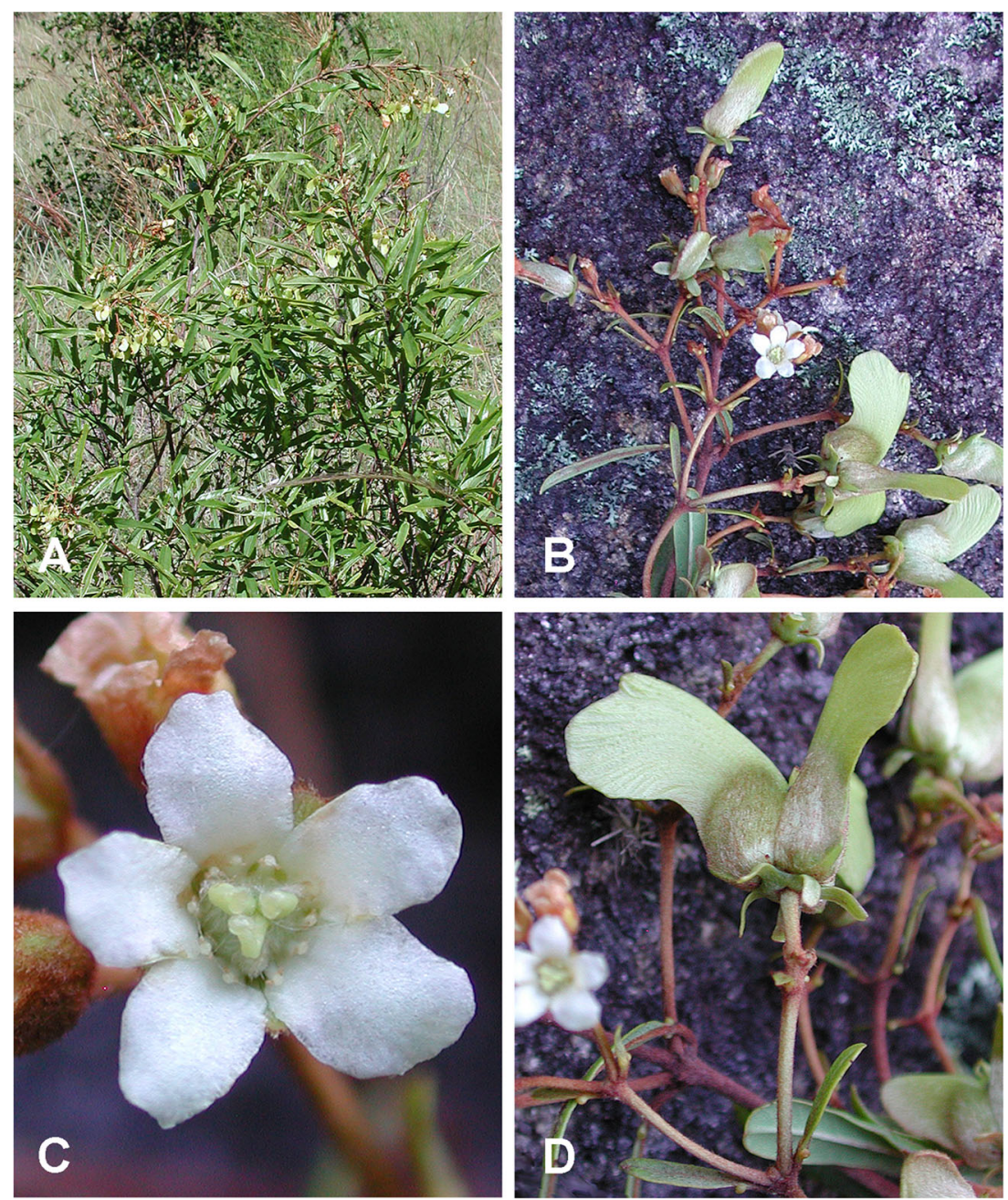

Fig. 2. Sphedamnocarpus andersonii. A. Habit. B. Distal portion of inflorescence. C. Pistillate flower with reduced androecium. D. Fruit. Photos by Thomas F. Daniel.

each pedicel subtended by a bract $1.1-$ $1.7 \mathrm{~mm}$ long and a pair of bracteoles $0.5-$ $0.7(-1) \mathrm{mm}$ long, bracts and bracteoles narrowly triangular. Sepals 5, 2-2.5 × 1.3-1.5 $\mathrm{mm}$, elliptical to oblong, glabrous adaxially, sericeous-tomentulose abaxially, eglandular. Petals 5, white to cream, claw $0.6-0.8 \mathrm{~mm}$ long, limb 3.5-4.2 × 2-3 mm, elliptical-oblong, margin subentire. Stamens 10, glabrous, the filaments connate at base, anthers with a large dark red connective. Ovary tricarpellate, densely hirsute, styles three, each with a large terminal stigma. Staminate flowers: filaments opposite sepals 1.7$1.8 \mathrm{~mm}$ long, those opposite petals 1.3-
$1.6 \mathrm{~mm}$ long, anthers $0.5-0.6 \mathrm{~mm}$ long; ovary $0.7-0.9 \mathrm{~mm}$ long, styles $1-1.1 \mathrm{~mm}$ long, distally bent to recurved. Pistillate flowers: filaments opposite sepals $1-1.3 \mathrm{~mm}$ long, those opposite petals $0.7-0.8 \mathrm{~mm}$ long, anthers ca. $0.3 \mathrm{~mm}$ long; ovary $1.1-1.2 \mathrm{~mm}$ long, styles $1.1-2 \mathrm{~mm}$ long, slightly incurved. Dorsal wing of samara 13-15 $\times$ 7-8 cm wide, very sparsely sericeous; lateral wings absent; nut $7-7.5 \mathrm{~mm}$ long, 2.5$3.2 \mathrm{~mm}$ in diameter, glabrescent, areole 2-3 $\times 2-2.5 \mathrm{~mm}$ wide; carpophore ca. $2 \mathrm{~mm}$ long; torus ca. $2.5 \mathrm{~mm}$ long.

Etymology. - The species is named for William Russell Anderson (1942-2013), foremost 
expert of Malpighiaceae, who first discerned it as undescribed.

Distribution and habitat.-Madagascar, Ihorombe Region, Isalo National Park; rocky and sandy slopes and grasslands, 800-900 m.

Phenology. - Collected with flowers from January through April, with fruits from January through March.

Additional specimens examined. MADAGASCAR. Ihorombe Region: Ranohira, Isalo, Jan 1963 (fl, fr), Bosser 17,889 (MO, P); Isalo, sur le grès vers le Km 710, 800 m, 29 Jan 1955 (fl), Cours 5034 (P); plateaux et vallées de l'Isalo à l'ouest de Ranohira, 1955, 28,665 (fl, fr), Humbert 28, 730 (fl), 28,736 (fl), 28,768 (fl) (all P); Isalo, Mar 1960 (fl, fr), Keraudren $1118(\mathrm{P})$; Massif de l'Isalo, à l'est. de Ranohira, près Andohakandrareza, SE de la piscine, $22^{\circ} 33^{\prime} 00^{\prime \prime} \mathrm{S}, 45^{\circ} 21^{\prime} 00^{\prime \prime} \mathrm{E}$, 14 Feb 1990 (fl, fr), Labat 2126 (MO, P); Ilakaka (Isalo), 21 Feb 1961 (fl, fr), Peltier 2978 (P); Isalo, 16 Apr 1965 (fl), Peltier 5518 (P); Isalo National Park, along RN7, 13 km SW from Ranohira, 22³8'10"S, 45¹9'15"E, 800 m, 18 Feb 1993 (fl), Phillipson 4104 (MICH, MO); aux environs du signal de l'Isalo-sud, à l'ouest de Ranohira, Feb 1955 (fl, fr), Service Forestier Madagascar (Capuron) 11,670 (P).

\section{Acknowledgments}

Karin Douthit drew the beautiful illustration. I thank Thomas F. Daniel (CAS) for sharing his photos of Sphedamnocarpus andersonii and two anonymous reviewers for the comments. The curators of $\mathrm{MICH}$ and $\mathrm{MO}$ kindly provided access to their collections. I am grateful to the curators and staff at $\mathrm{P}$ for their generous assistance and hospitality extended to William R. Anderson and me during our visit in 2007. This study was supported in part by a grant from the National Science Foundation to the University of Michigan (DEB-0543909).

\section{Literature cited}

Arènes, J. 1943. Révision du genre Sphedamnocarpus Planchon (Malpighiacées). Notulæ Systematicæ (Paris) 11: 97-123.

Davis, C. C. \& W. R. Anderson. 2010. A complete phylogeny of Malpighiaceae inferred from nucleotide sequence data and morphology. American Journal of Botany 97: 20312048.

Launert, E. 1961. Studies in African Malpighiaceae. Boletim da Sociedade Broteriana, sér. 2, 35: 29-49. 1963. Malpighiaceae. In: A. W. Exell et al. (ed). Flora Zambesiaca 2(1): 109-225. Crown Agents for Oversea Governments and Administrations, London.

Niedenzu, F. 1915. Malpighiaceae palaeotropicae. Arbeiten aus dem botanischen Institut der Kgl. Akademie (vorm. Kgl. Lyceum hosianum) in Braunsberg, Ostpreussen VI: $1-63$.

. 1928. Sphedamnocarpus. In: A. Engler (ed.). Das Pflanzenreich, 141 (Heft 94): 252-258. Wilhelm Engelmann, Leipzig.

Pohl, R. W. 1965. Dissecting equipment and materials for the study of minute plant structures. Rhodora 67: 95-96. 